\title{
VOCATIONAL AND TECHNICAL EDUCATION: PANACEA FOR JOB CREATION AND NATIONAL DEVELOPMENT IN NIGERIA
}

\author{
Dr. D. MOSES \\ Department of Electrical Technology Education \\ Modibbo Adama University of Technology, Yola, Adamawa State \\ $+2348034477990 ;+2348051774711$ \\ https://doi.org/10.37602/IJSSMR.2020.3309
}

\begin{abstract}
This paper discussed Vocational and Technical Education as a panacea for job creation and national development. Despite the growing level of un-employability of graduates, it is disturbing to observe that many youths still scramble to acquire entrepreneurship skills. The dream of many secondary school leavers is to go to higher institutions and study one of those lucrative courses which they feel can confer a sense of pride in them. As technological changes occur at unprecedented speeds, it becomes increasingly important to develop mechanisms that can foster skills highly demanded in emerging careers. There is no gainsaying the fact that Vocational and Technical Education and Training (VTET) is what Nigerians need to keep pace with employment demand in a technologically-driven economy and for national development. The question still remains, what reforms are necessary for VTE to enable it to take the lead in equipping young Nigerians with relevant life skills that will foster the creation of functional jobs to impact positively on the nation's development. It was concluded that our youths need education empowerment, the type offered by Vocational and Technical Education which is designed to equip the learners with skills and competencies, hence, there needs to make stringent efforts to vocational education in Nigeria and that the government at both federal and state levels should finance and equip Vocational and Technical institutions or departments with necessary facilities and infrastructure that will enhance effective teaching and learning in such a way that required skills for selfemployment will be developed in the learners.
\end{abstract}

Keywords: Vocational and Technical Education, Job Creation, National Development, Self-Employment, Emerging Careers

\subsection{INTRODUCTION}

In the late 1980s, Nigeria came to recognize what the developed nations recognized in the 19th century, the need to put in place a viable and sustainable Vocational and Technical Education system, as a way out of technological and economic dependence on the developed nations of the world. According to Abdullahi (1990), Nigeria had no option but to embrace technical and vocational education because the former system which placed less emphasis on vocational and technical skills and knowledge falls short of the developmental needs of the nation. To address the shortcomings of the system of education, the 1977 National Policy on 


\section{International Journal of Social Sciences and Management Review}

Education was revised in 1981. In this edition, the policy outlined steps aimed at improving the quality and standard of Vocational and Technical Education (VTE) in Nigeria as a major stepping stone for the rapid transformation of the nation (Okoro, 2000). In stressing the importance of this form of education, Olaitan (1996) noted that VTE is essential for any nation's technological development and freedom from economic slavery, hence no sacrifice should be considered too great in developing it, because of the rewards and sustained social and economic benefits.

Onanuga (2002) and Ekpenyong (2008) noted that VTE is a vital component of the present system of education in Nigeria because it prepares students to be effective individuals and members of society. Furthermore this form of education according to Onanuga, enables citizens to appreciate societal norms and values, develop a proper attitude to life, acquire saleable skills that would enable them be self-employed or perform effectively on the job when employed.

Despite Nigeria being endowed with both human and material resources, gross mismanagement, profligate spending, kleptomania and adverse policies of various governments of Nigeria, these resources have not been optimally utilized; these resources have not been adequately channelled to profitable investments to bring about maximum economic benefits. As a result of the foregoing, Nigeria has been bedevilled with unemployment and poverty (Iwayemi, 2013). National development is the exploitation and utilization of both human and material resources to improve the lots of a nation. It involves the improvement of the social welfare of the people of that nation. Education, on the other hand, is particularly acknowledged as the cornerstone to any form of development as well as democratic processes. In Nigeria, vocational and technical education in the form of education perceived to be the greatest weapon that can be used to bring or achieve quick desirable changes or development in the country's economic, political, sociological and human resources. It is based on his premises that Tika (2015) recommends that ministry of education and other stakeholders in government should join forces to ensure effective implementation of vocational and technical education with the view of improving the quality of skilled workforce for the benefit of the industries.

Technology unarguably emerged as the dominant factor in determining the wealth of a nation. The technology applied in Nigeria today has been imported which impact negatively to the development of our indigenous technology (Habibu, 2007). No nation can be selfreliant without developing and utilizing her indigenous talents and technologies. According to Lawal (2010), development in Vocational and Technical Education is intimately linked to the general trends in the economy and labour markets which are particularly susceptible to the effects of technology changes.

It is based on the background that this study finds it worthwhile to address the following questions in order to do justice to the subject matter. First, why are Nigerians suffering in the midst of plenty? Secondly, if other growing economies, especially in the Asian continent, are flourishing in the area of entrepreneurship, why can't Nigeria do likewise, if not better? Third, if Vocational and Technical Education and Training (VTET) is well positioned, can it serve as a panacea to unemployment in Nigeria? The scope of this paper is defined by these questions. 


\section{International Journal of Social Sciences and Management Review}

The importance of Education to the general well-being of mankind cannot be overemphasized. Education, as he perceives, is a fundamental human right. Lawal (2010) explains that the relationship between education and development had been established, such that education is now internationally accepted as a key development index. It is in recognition of this importance that the international community and governments all over the world have made commitments for their citizens to have access to education. Odukoya (2009) posited that over the years, Nigeria has expressed a commitment to education with the belief that overcoming illiteracy and ignorance will form a basis for accelerated national development. He noted, however, that regardless of the incontrovertible evidence that education is crucial to the development of the community and the nation, there remain inequalities in access to education. Also, he reiterated that despite its potential for levelling opportunities, education is pathetically used to perpetuate inequalities. Millions according to him of the poor people are still being excluded from the processes and outcomes of Education. In order to improve the level of the educational system in Nigeria, Olajide (2015) recommended improved policy on information and communication technology (ICT), the need for a good understanding of the process of policy formulation, the need for political lobbying and advocacy in order to solve the logistic problem and bureaucratic bottlenecks; implementation of the policy on Teachers' Registration Council, the dire need for a new system of education, improved policy on vocational and technical education; harmonization of the differential remunerations for graduates.

\subsection{Vocational and Technical Education in Perspective}

Vocational and Technical Education (VTE) is a planned programme of courses and learning experiences that begins with an exploration of career options, supports basic academic and life skills and enables the achievement of high academic standards, leadership qualities, preparation for industry define work and advanced and continuing education. Abdulrahaman (2017) described VTE as a programme with various branches that can transform Nigeria into a producer/manufactures nation from its present status of a consumer/importer nation. Its various courses are career-oriented and thus arms graduates with skills to work in the choose trade or profession. The current Nigeria National Policy on Education places great emphasis on Vocational and Technical Education as an integral part of national development strategy. National Policy on Education (2013) describes Vocational and Technical Education as a comprehensive term referring to those aspects of the education process involving in addition to general education the study of technology and related science and the acquisition of practical skills, attitudes, understanding and knowledge relating to occupation in various sectors of economic and social life. For a country to advance both socially economically and technologically, its citizens must be productive and creative. It must have a productive citizen majority of which can be job creators rather than job seekers. Lawal (2010) describe vocational and technical education as those types of education that prepare people who could apply the relevant practical skill to make positive changes within their society and afford a self-dependent life. This form of education has been attesting severally as an education that provides self-employment, enhance productivity and self-reliance. It seduces the overdependence of school graduates on government own jobs. Vocational and technical education gives an individual the skills to live learn and work as a productive citizen in a global society. This is why Chukumerije (2011) submitted that Vocational and Technical Education remains the only imperative for economic development in Nigeria. He appraised different effects and 


\section{International Journal of Social Sciences and Management Review}

policies towards economic development but all to no avail. He, however, identified some reasons for the desultory performance to include inadequate infrastructure and facilities, the serious dearth of academic staff with cognate practical experience relevant for the training of students to the meet the contemporary needs of industry and employers, wide disconnection between institutions and industry, weak support by industries to institutions' programmes, inadequate budgetary provision for VTE, absence of a National Qualifications framework and inadequate regulatory and monitoring activities among others. However, Olabode, Badmus and Ademola, (2010) proffered some coping measures which include re-definition of the status of occupational training, rule of law, basic and secondary education, restructuring of tertiary education, and need for improved budgetary allocation to the VTE in Nigeria.

Moemeka (2013) opined that the status and rating of nations today in the League of Nations is dependent on the capacity to meet the domestic needs of citizens as positing products in the global marketplace. He believes that innovation in Vocational and Technical Education (VTE) occupies an important place inability of nations to achieve this. He, therefore, advocates needed innovations in the curriculum of technical and vocational institutions through integration of entrepreneurship education programme as well as improvement in the entrepreneurship qualities of Technical and Vocational graduates.

\subsection{Constraints of Effective Vocational and Technical Education in Nigeria}

It is unfortunate that as Vocational and Technical Education is expected to meet the aspiration of Nigerian society, to shape its future and provide solutions to some of its social, political and economic issues. The development of this educational system has been identified with some constraints, which serve as hindrances to its development. The problems may not be far different from what the system has experienced in the last three decades, but many of which are in the increase as stated by Habibu (2007). The following are some of the constraints militating against effective Vocational and Technical Education in Nigeria:

$\checkmark$ The misconception of the definition and meaning of the programme

$\checkmark$ The wrong societal perception of the Vocational and Technical Education programme

$\checkmark$ Weak government policy and poor implementation

$\checkmark$ Inadequate funding of the programme

$\checkmark$ Lack of basic facilities and workshops

$\checkmark$ Inadequate qualified personnel, leaders and administrators

$\checkmark$ Lack of power supply in existing workshops which limit the conduct of practical

$\checkmark$ Problems related to the curriculum of the programme

$\checkmark$ Influence of politics on Vocational and Technical Education programme

\subsection{Vocational and Technical Education and Job Creation}

The central concern of technical education and job creation revolves around the capacity building/entrepreneurial ventures by individuals in training. This concern is predicated upon the fact that productive work and employment are central elements of development. Sustained economic growth and sustainable development, as well as the expansion of productive employment, must go hand in hand. Productive employment is strictly based on skills acquisition in jobs of great importance to the nation. In this regard, creating enough 


\section{International Journal of Social Sciences and Management Review}

jobs and productive employment to break the vicious cycle of poverty remains one of Africa's most daunting development challenges (UNESCO, 1995). The region's economies have not achieved adequate employment creation or enough labour absorption capacity-to keep pace with population growth, urbanization and the rising expectation of their citizens. In Nigeria, $80 \%$ of the youth are unemployed and $10 \%$ are underemployed (Dike, 2009). The solution to this problem lies in creating jobs for Nigerian youth.

It is believed that vocational and technical education is the only key to unlock Nigeria out of the present unemployment predication. As defined by Calhoun and Finch in Olajide (2015), vocational education is "an organized educational programme which is directly related to the preparation of the individual for paid or unpaid employment or for additional preparation for a career requiring other than a baccalaureate or advanced degree". Essentially unemployment may apply to any factor of production but in most cases, it applies to labour as a factor of production. In a general sense, unemployment is defined as a state of joblessness. But this definition is too wide to be satisfactory because many categories of people who are without work should not be classified as "unemployment" in any meaningful sense. For instance, various labour codes prescribe lower and upper age limits for the labour force (those who can be legitimately regarded as either working or available for work). This implies that those who are below the lower limit or above the upper limit are regarded as falling outside the labour force. According to Olajide (2015) when such people are without work, even though they may be willing and able to work, they do not feature in unemployment statistics. Even within the accepted age limits, there are people who should not be regarded as "unemployed" even though they may be 'idle', these include those who are physically and/or mentally handicapped - such as cripples and lunatics or imbeciles - full-time students and trainees, and housewives who devote all their time entirely to taking care of their homes. Another major problem encountered in the definition of unemployment is the determination of the minimum period of idleness that qualifies a person to be classified as 'unemployed'. Usually, in labour force surveys, people who are without work during the reference period varies from one to two days in some countries, to one week and even to three months in other countries. However, the general requirement is that for people to be regarded as unemployed, they must be actively seeking for work (Osinubi, 2005).

Oloidi (2013) submitted that over the years Nigeria had been promoting theories, principles and concepts instead of the practice of Technology, hence, the country has been rated very low in the area of Production and Industrialization. From the foregoing, efforts have been intensified to review relevant literature in relation to the course of study. It is therefore evident that Nigeria is bedevilled with a high level of unemployment. It has been proved that this menace could be ameliorated if VTE is repositioned which is the thrust of this paper.

\subsection{Vocational and Technical Education as a Tool for National Development}

Vocational and Technical Education (VTE) is a tool for addressing the economic, political and social crises that are threatening the stability of this nation. Vocational and Technical Education is extremely important in improving a nation's industries while supplying a capable workforce. More emphasis needs to be laid on VTE for it to reduce unemployment rates among Nigerian youths. The rising unemployment rate, lack of skilled workers, and high dropout rates called for effective implementation of Vocational and Technical Education 


\section{International Journal of Social Sciences and Management Review}

(VTE) because an idle hand is the devil workshop. Danko (2006) defined Vocational and Technical Education as the core of both the individual's and the society's economy. Sanusi (2016) stressed further that through the acquisition of skills, individuals could explore their environment and harness the resources within it, which could serve them and the society since the wealth of the society determines to a large extent the development of that society. Adegbenjo (2013) saw Vocational and Technical Education as an organised programme of Education that prepares learners for entrance into a particular chosen vocation.

Vocational and Technical Education is the basis for rapid technological advancement. In Nigeria, there has been an emphasis in recent times on improving Vocational and Technical Education in tertiary institutions basically for combating unemployment and poverty, as well as improving the economic performance of the nation. Vocational and Technical Education is an integral part of national development strategies because of its impact on productivity and economic development (Sanusi, 2016). It is an ingredient towards excellent management and development of human resources; which is the bedrock of the development of other sectors. VTE enhances the productivity of workers in their chosen careers and increases their earnings throughout their lifetime. The society needs competent auto repairers/mechanics, truck drivers, carpenters, plumbers, electricians, computer engineers, database and web/network technicians, bookkeepers, clerks, medical technicians, vocational nurses, marketers, dressmakers, home managers, and secretaries among others to function well. Vocational and Technical Education provides the much needed skilled manpower in these various spheres. Vocational and Technical Education develops employability skills in the students or youths that pursue this programme; for them to be self-employment or self-reliant in order to contribute to the national growth of this country (Abdulrahaman, 2013). If the government can finance and equip VTE adequately, offer free education and encourage the youths to go for VTE in any of the institutions offering the programme; either in the Technical College, Polytechnic, College of Education and University; they will be empowered and selfemployed instead of looking for insufficient white-collar jobs. Above all, Vocational and Technical Education holds the key to national development since it is a catalyst for creating employment opportunities.

\subsection{Restructurings Needed in Vocational and Technical Education for Job Creation and National Development}

With mountains of challenges faced by VTE, rapid technological developments and advancements are very much on top of these challenges (Majumdar, 2011). Te demand for high-level skills due to transformative nature of jobs and requisite industry needs is resulting into high unemployment rate among VTE graduates as alarmed by UNESCO-UNEVOC; the international centre for TVET based in Bonn, Germany. The centre states that " everyday people worldwide gain access to basic education, and this has sparked career expectations and raised hope for better futures amongst many young people, yet, these hopes are not satisfied", and as such, "there is high job insecurity, skills mismatched and growing youth unemployment" These challenges according to UNESCO-ENEVOC, are putting increasing pressure on education systems to provide relevant education for the world of work, and the unanswered question remains "how do we deal with these challenges"? To answer this question, VTE must initiate and sustain practical reforms in order to make it relevant for Job creation and national development in Nigeria. Amongst emerging reforms necessary in VTE 


\section{International Journal of Social Sciences and Management Review}

for Job Creation and national development, Yalams (2019) outlined three basic steps called change agenda in reforming TVET curriculum for job creation and national development, which are:

\subsection{Greening Vocational and Technical Education Concept}

This is aimed at delivering knowledge and practices towards a more environmentally friendly, enhancing decision-making and lifestyle in a more ecologically responsible manner. According to Yalams (2019), all aspects of education as an industry revolves around three cardinal points. The people, the gains/profits of the system and the planet/environment (PPP). Short-term targeted training typically following initial education or training and aimed at supplementing, improving or updating knowledge, skills and/or competences acquired during previous training (CEDEFOP, 2008). Based on this consideration, the UNESCO-UNEVOC (2014) has advocated an approach for sustainable transformation of VTE institutions globally from a non-sustainable (Red) into a more sustainable (Green) one. Greening VTE OR GVTE is an emerging concept emanating from UNESCO-UNEVOC as part of fulfilment of UN's decade for Education for Sustainable Development (ESD), which has now translated into what is called Sustainable Development Goals (SDGs). Majumdar (2011) describes GVTE as "a way of thinking in a sustainable manner as it relates to acquiring, consuming and disposing of utilities, proactive actions aimed at improving human wellbeing and social equity while significantly reducing environmental risk and ecological scarcities" The GVTE concept is aimed at transforming our campuses, changing societal attitudes, land spaces, people's culture and lifestyles towards becoming more environmentally friendly. Within the GVTE, framework, the emphasis is on waste management; renewable energy; environmental protection; community service programmes among others. It will provide jobs that contribute to preserving or restoring environmental quality, while also meeting longstanding demands and goals of the labour movement, such as adequate wages, safe working conditions and workers' rights. According to Majumdr (2010), GVTE has been introduced to play an important role in the transition to green growth and societies and to create a sustainable future. A green economy requires a workforce with the appropriate skills and training which is lagging behind at present; a place for VTE to fill. The concept of GVTE is to provide knowledge, abilities, values and attitudes needed to live in, develop and support a sustainable and resource-efficient society (CEDEFOP, 2012). Framework for GVTE according to Majumdar (2012) consists of five layers as follows: Greening the Campus, Greening the Curriculum, Greening the Research, Greening the Community and Greening the Culture.

\subsection{Restructuring VTE through the STEM Integration Concept}

For the optimal achievement of VTE goals in Nigeria, the integration of Science, Technology, Engineering and Mathematics (STEM) is ideal. Science is the study of the natural world, which includes the laws of nature associated with physics, chemistry and biology. It is known as a body of knowledge that has been accumulated over time and a process that generates new knowledge (Reeves 2015). Technology, on the other hand, is considered as the art or craft of "modifying the natural world to meet the needs and wants of people" (ITEEA 2015). It is human innovation that involves the generation of knowledge and processes to develop systems to solve problems and extend human potential. Engineering as defined by the ITEEA (2015) is considered as the application of Mathematics and Science to 


\section{International Journal of Social Sciences and Management Review}

create Technology. Engineering is about problem-solving which uses the Engineering Design Process to create products or system that would solve problems. Mathematics, on the other hand, is a language of numbers, operations, patterns and relationships. It is used in Science, Engineering and Technology to meet human needs and wants. Putting the four fields together forms the acronym 'STEM'. But the situation currently in the Nigeria VTE curriculum and delivery system is such that, institutions teach each and related disciplines in 'Silos'. This approach does not help the 21st Century learners to think critically and devise sustainable solutions to existing problems as against an integrated approach. In today's globalization world of new inventions and innovations where most developments involve STEM education workforce is needed to stay relevant and competitive. Thus, for a country to fully develop, it will need to incorporate the integrated STEM approach at all levels of its instructional delivery. The importance of iSTEM education therefore in the VTE curriculum can be seen through the following reasons: since VTE is all about career preparation, students are shown how their careers are connected to STEM in VTE, bearing in mind that many of the skills most needed to compete in the global market of the 21 st Century are technical/vocational in nature. The integration of STEM education into VTE curriculum helps build products' needed for the world of work.

\subsection{Restructuring VTE through Competency-Based Approach}

The National Board for Board for Technical Education (NBTE) in Nigeria, recently just started the implementation of National Vocational Qualifications (NVQ) as part of the VTE reformation process. This newly introduced system employs the Competency-Based Education and Training (CBET) or Competency-Based Learning (CBL) approach in which learners are trained and certified based on their attainment of competencies in any given career or skills clusters. Competency is defined by Wahab (2018) as the individual's ability to use, apply and demonstrate a group of related awareness, knowledge, skills and attitudes in order to perform tasks and duties successfully, which can be measured against well-accepted standards (levels) required in employment against provided evidence at the work location. One's competency affects both his/her job responsibility and performance on the job; and these usually fall into two categories, namely technical and behavioural competencies. The Competency-Based Education and Training curriculum wherever employed aims at preparing learners more effectively for real workplaces, which means that the acquisition of competencies takes into account the requirements of companies and industry that are affected by globalization and the modern technology. This approach will help in building strong and relevance-criterion manpower and by extension make available job opportunities. The strategy of Competency-Based VTE is based around "Occupational competencies" which are established for each career field and for each job title. According to Wahab (2018), a Competency-Based VTE system generally uses a combination of powerful techniques to ensure that the needs (demands), of different industry sectors, are addressed, courses or competency-based training programs are developed, competency-based assessments/verifications are conducted, employees/apprentices trainees/students are efficiently trained and competent. Techniques such as Management Information System (MIS), Knowledge Management (KM), Monitoring and Evaluation (M\&E) and Competency Assurance Management System (CAMS) are generally used. Competency-Based Learning (CBL) and Modules" system are designed to enable the students to obtain the practical professional skills that meet the private sector demand, an approach which aims at teaching 


\section{International Journal of Social Sciences and Management Review}

the students concrete skills rather than abstract learning (Stabback, 2016). With the Competency-Based VTE system, usually, five (5) levels of competencies are adopted by most countries, although some may choose to have more or less. The common levels are Level 1(semiskilled), Level 2-skilled), Level 3-(craft man) Level 4-(technicians), and Level 5(expert). Every level has different learning and teaching objectives. The difference in the learning objectives requires different curriculum approaches and competence development. Thus, for the VTE curriculum in Nigeria to be well transformed, deploying the CBET is not an alternative but necessity.

\subsection{CONCLUSION}

The solution to unemployment and by extension national development in the country is education empowerment. The youths need education empowerment, the type offered by Vocational and Technical Education which is designed to equip the learners with skills and competencies which prepare individuals for self-employment that brings total development to individuals and the country at large. If the youths have hope of earning incomes and are empowered financially, the prevailing insecurity in this country will be reduced and the country will be developed.

\subsection{RECOMMENDATIONS}

Based on the conclusion, the following recommendations were proffered:

1. The government and other relevant bodies should make stringent efforts to vocational education in Nigeria.

2. The government should finance and equip Vocational and Technical institutions or departments with necessary facilities and infrastructure that will enhance effective teaching and learning in such a way that required skills for self-employment will be developed in the learners.

3. The government should make Vocational and Technical Education free in Nigeria to enable the youths with poor financial background to have access to Vocational and Technical Education in order to alleviate poverty which is dragging this country backwards in terms of development.

\section{REFERENCES}

Abdullahi, M. D. (1990). Management of science, technology and mathematics education in Nigeria of the 1990s. Education Today, 3(4), $170-175$.

Abdulrahaman W. L. (2013). Vocational and Technical Education, a tool for national development in Nigeria. Mediterranean Journal of Social Sciences, 4(8), 85-89.

Adegbenjo, A. O. (2013). Alternative sources of funding Vocational and Technical Education in Nigeria. A paper presented at the 6th national conference of School of Vocational and Technical Education, Federal College of Education (Special) Oyo, Oyo State between 3rd and 6th June, 2013. 


\section{International Journal of Social Sciences and Management Review}

Volume: 03, Issue: 03 "May - June 2020"

ISSN 2582-0176

CEDEFOP (European Centre for the Development of Vocational Training). (2008). Terminology of European education and training policy: a selection of 100 key terms. Luxembourg.

CEDEFOP. (2012). Research paper on green skills and environmental awareness in vocational education and training. Synthesis Report. Luxembourg, CEDEFOP. http://www.cedefop.europa.eu/en/publications-and-resources/publications/5524 (Accessed 16 July 2019).

Chukwumerije, U. (2011). The Imperatives of Technical and Vocation Education in Nigeria. Convocation Lecture, Anambra State University. December 7, 2011.

Danko, A. (2006). Definition, Scope, Phylisophy, Objective and Characteristics of Vocational And Technical Education, Chapter One, in Usman, A.Z., Aliyu, M.M., Kurya U. L., and Kurfi, A. K. (Eds.) Entrepreneurship Education for Vocational and Technical Education Students Benchmark Publishers, Kano.

Dike, V. E. (2009). Technical and Vocational Education: key to Nigeria's development. http//www.triumphnewspapes. com/tech 30320og. htm Retrieved on 26 $-7-2019$.

Ekpenyong, L. E. (2008). Foundation of Vocational and Technical Education: Evolution and practice: Benin City: Ambik Press Ltd.

Habibu, R. G. (2007). Technology Education as a Tool for Productivity and Sustainable Development in Nigeria. A paper presented at the 20th annual National conference of National Association of Teachers of Technology (NATT) at Kaduna Polytechnic, 5th - 9th November, 2007.

Iwayemi, A. (2013). Youth Unemployment in Nigeria: Challenges and Way Forward. Being paper presented at the World Bank, Regional Workshop on Youth Employment, Abuja. July 23 and 24, 2013.

Lawal, A. W. (2010). Re-branding Vocational and Technical in Nigeria for Sustainable National Development, Problems and Prospect. A paper presented at the 1st National conference of School of Business Education, Federal College of Education (Technical) Bichi, 1st - 4th November, 2010.

Majumdar S. (2011) "Greening TVET: Connecting the Dots in TVET for Sustainable Development". Proceedings of the International Conference on ESD in TVET organized by CPSC, IVETA in Went and TESDA, Nov. 3-5, 2010, Manila, Philippines.

Moemeke C. D. (2013): Innovating science education for technical entrepreneurship: The curriculum dimension. Journal of Business Entrepreneurship, 2(2), 21-33.

Odukoya, D. (2009). Formulation and Implementation of Educational Policies in Nigeria. Position paper presented at ERNWACA, University of Lagos, Nigeria. 


\section{International Journal of Social Sciences and Management Review}

Volume: 03, Issue: 03 "May - June 2020"

ISSN 2582-0176

Okoro, O. M. (2000). Programme evaluation in education. Nsukka: pacific Publishers.

Olabode, B. O., Badmus, A. S. and Ademola, E. A. (2010). The Role of Technical and Vocational Education in the Nigerian Development Agenda (Vision 20:2020) ASUP Conference paper held in Federal Polytechnic, Ilaro, Ogun State, Nigeria

Olaintan, S. O. (1996). Vocational and technical education in Nigeria: Issues and analysis, Onisha: Noble Graphic Press.

Olajide, S. E. (2015). Repositioning Vocational and Technical Education toward eradicating unemployment in Nigeria. International Journal of Vocational and Technical Education, 7, 54-63.

Oloidi, O. (2013). Knowledge Scientification in Nigeria's Tertiary Institutions: Implications for Art and Technology. Paper presented at the $6^{\text {th }}$ Annual Lecture of the School of Environmental Technology, Federal University of Technology, Akure, Nigeria.

Onanuga, P. A. (2002). Limiting factors in stimulating and sustaining interest in psycho productive skills Acquisition in secondary school Agricultural Science being a paper presented at the $4^{\text {th }}$ National conference of League of Researches in Nigeria at University, Jos 23-26, October.

Osinubi, T. S. (2005). Macro econometric analysis of growth, unemployment and poverty in Nigeria, Pak. Econ. Soc. Rev. 48(2):249-269.

Reeves, E. M. (2015). STEM Integral to TVET: The Nexus. A paper presented at the Caribbean International Conference on TVET May 13-15, 2015. Montego Bay, Jamaica.

Sanusi, R. A. (2016). The Potential of Vocational and Technical Education in Addressing Nigeria's Contemporary Socio-Economic and Political Challenges. Being a paper presented at the 6th National Conference of the Faculty of Administration, Nasarawa State University, Keffi.

Stabback, P. (2016). What makes a Quality Curriculum? In-Progress Reflection No. 2 on Current and Critical Issues in Curriculum and Learning. IBE UNESCO International Bureau of Education. UNESCO. (2012). World TVET Database Palestine. Bonn:

Tika, T. J. (2015). Assessment of the cognitive and psychomotor skills performance of students in bricklaying, blocklaying and concreting trade in technical colleges of Adamawa State. An Unpublished doctoral dissertation; department of Technology Education, Modibbo Adama University of Technology, Yola.

UNESCO, (1995). World Education Report

Wahab, M. (2018) Competency-Based Education and Training in TVET/Career and Technical Education. Retrieved from: UNESCO-UNEVOC e-Forum, http://www.unevoc.unesco.org/e-forum 


\section{International Journal of Social Sciences and Management Review}

Volume: 03, Issue: 03 “May - June 2020"

ISSN 2582-0176

Yalams, S. M. (2019) Curriculum reforms in TVET for global competiveness. A lead paper presented at the $27^{\text {th }}$ International Conference of the Association of Vocational and Technical Educators of Nigeria (AVTEN) Ebonyi State University, Abakiliki, Ebonyi State on $23^{\text {rd }}-27^{\text {th }}$ July, 2019. 